\title{
First record of Toxodontidae (Mammalia, Notoungulata) from the late Miocene-early Pliocene of the southern central Andes, NW Argentina
}

\author{
Ricardo A. Bonini, ${ }^{1}$ Gabriela I. Schmidt, ${ }^{2}$ Marcelo A. Reguero, ${ }^{1}$ Esperanza Cerdeño, ${ }^{3}$ \\ Adriana M. Candela, ${ }^{1}$ and Natalia Solís ${ }^{4}$ \\ ${ }^{1}$ División Paleontología de Vertebrados, Facultad de Ciencias Naturales y Museo, Paseo del Bosque s/n, B1900FWA La Plata, Argentina \\ 〈rbonini@fcnym.unlp.edu.ar〉; 〈regui@ fcnym.unlp.edu.ar〉; 〈acandela@ fcnym.unlp.edu.ar〉 \\ ${ }^{2}$ Laboratorio de Paleontología de Vertebrados, Centro de Investigaciones Científicas y Transferencia de Tecnología a la Producción (CICYTTP- \\ CONICET), Materi y España, 3105, Diamante, Entre Ríos, Argentina 〈gschmidt@ cicyttp.org.ar〉 \\ ${ }^{3}$ Paleontología, IANIGLA, CCT-CONICET Mendoza, Avda. Ruiz Leal s/n, 5500 Mendoza, Argentina 〈espe@ mendoza-conicet.gob.ar〉 \\ ${ }^{4}$ Museo de Geología, Minería y Paleontología, Instituto de Geología y Minería, Universidad Nacional de Jujuy. Avda. Bolivia 1661, 4600 San \\ Salvador de Jujuy, Argentina〈nsolis@idgym.unju.edu.ar〉
}

\begin{abstract}
A new species of toxodontid notoungulate, Xotodon maimarensis n. sp., is described from the Maimará Formation (late Miocene-early Pliocene), Jujuy Province, northwestern Argentina. This is the first record of a toxodontid from the Eastern Cordillera. The specimen is housed at the Museo de Geología, Mineralogía y Paleontología, Instituto de Geología y Minería de la Universidad Nacional de Jujuy. It consists of an incomplete mandible preserving the right mandibular ramus with part of the dental series, partially preserved symphysis with all the incisors, and a small portion of the left ramus without teeth. The following characters distinguish it as a new taxon: symphysis long and narrow with slight divergence of its lateral borders; strong procumbence of lower incisors and deeply implanted i3; chin angle lower than in X. major and X. cristatus and bulging labial keel limiting strong lateral concavities. Comparative analysis in the context of the recently revised Neogene Toxodontidae indicates that the Maimará specimen shares mandibular features and dental characters with Xotodon and Mixotoxodon, differing from the latter by the more upraised symphysis. The phylogenetic position of Xotodon maimarensis n. sp. supports the taxonomic interpretation of the studied specimen as a new species of Xotodon. This new Toxodontidae increases the knowledge of the diversity and radiation of this group of notoungulates in northwest Argentina.
\end{abstract}

\section{Introduction}

Toxodontidae (Notoungulata) is one of the most diverse endemic clades of South American native ungulates that occurred from the Oligocene to the Late Pleistocene (Madden, 1990; Nasif et al., 2000; Bond et al., 2006). They are represented by medium- to large-sized terrestrial herbivores that are characterized by their specialized anterior dentition (high-crowned, heteromorphic incisors and tusk-like i3), which evolved from high-crowned to ever-growing cheek teeth since the middle Miocene (Madden, 1990, 1997; Bond et al., 2006).

South American toxodontids are presently classified into two subfamilies (Nasif et al., 2000): Nesodontinae and Toxodontinae. Nesodontines represent the oldest subfamily, recorded in Patagonia (Argentina) from the late Oligocene (Deseadan) to the middle Miocene (Friasian and Colloncuran), the late Oligocene (Deseadan) of Bolivia, and the early Miocene Chucal Fauna in Northern Chile (Croft et al., 2004).

In the Neogene of Argentina, toxodontines are well represented in the northwestern provinces of Tucumán and Catamarca (Moreno and Mercerat, 1891; Rovereto, 1914; Riggs and Patterson, 1939; Marshall and Patterson, 1981; Nasif et al., 2000; Bonini et al., 2011; Bonini, 2014), and the west-central provinces of San Luis, San Juan, and Mendoza (Cuyo Region; Rovereto, 1914; Pascual, 1965; Contreras and Baraldo, 2011; Forasiepi et al., 2011, 2015). The latest record of this family corresponds to the Late Pleistocene, in archeofaunal contexts (Madden, 1990, 1997) of Argentina, Brazil, Uruguay, Peru, Bolivia, Ecuador, Venezuela, and Colombia (Nasif et al., 2000; Bond et al., 2006). Toxodontines also have been recorded in North and Central America in the latest Pleistocene (Lundelius et al., 2013; Rincón, 2011).

In this contribution, we present the first description of a toxodontid from the Jujuy Province, adding to the other northwestern Argentinean Neogene records (Fig. 1.1). The studied specimen, JUY-P 49, had been previously mentioned as a possible new taxon by Reguero et al. (2011). We present herein its taxonomic and phylogenetic affinities, and discuss the temporal and biogeographic implications of the group.

\section{Geologic setting}

The late Miocene-early Pliocene Maimará Formation (Salfity et al., 1984) represents a continental sequence cropping out along the intermontane Quebrada de Humahuaca Basin in the Eastern Cordillera of the southern Central Andes of NW 


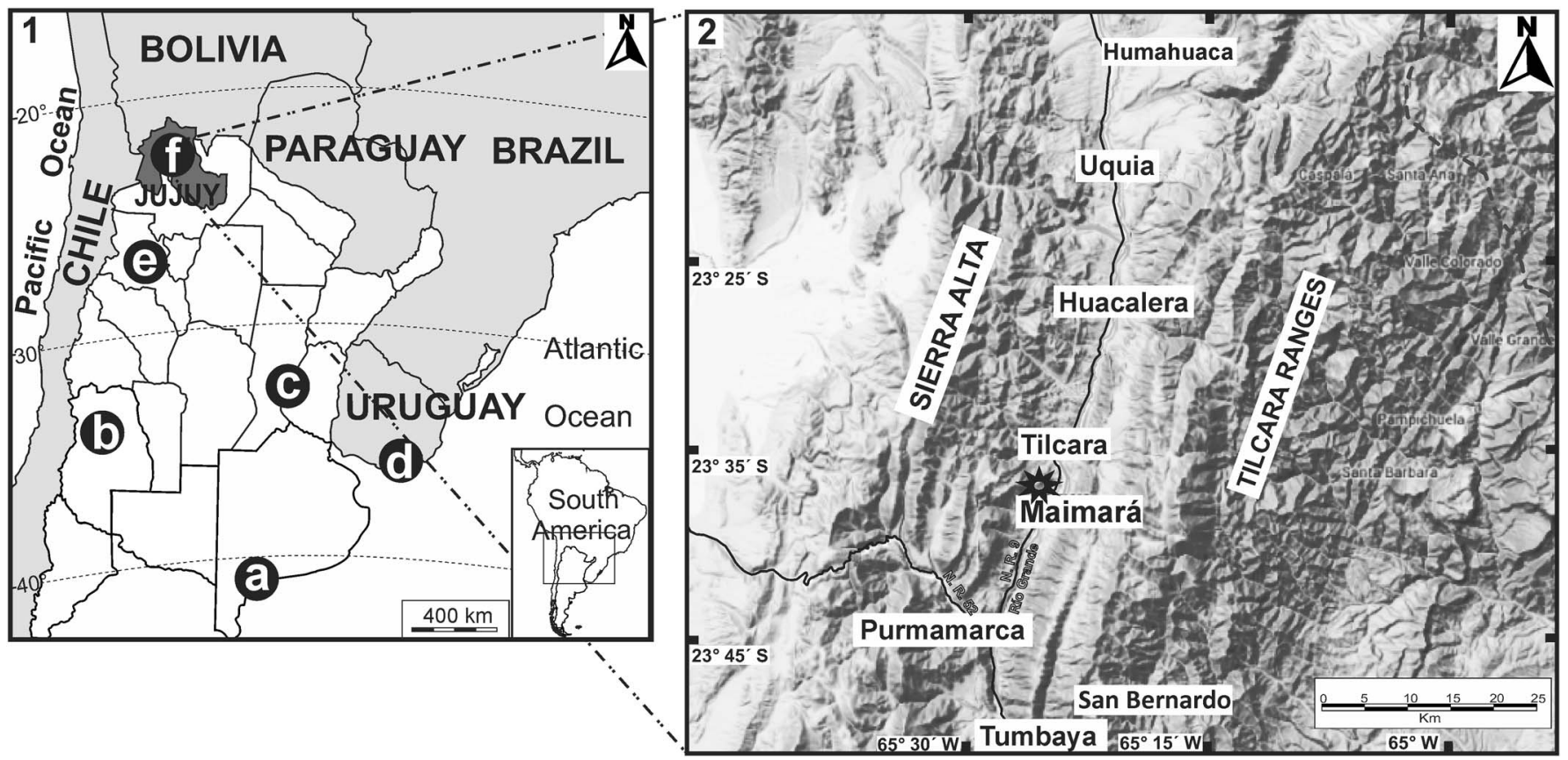

Figure 1. Map showing the geographical position of localities mentioned in the text: (1) Neogene localities of Argentina with record of Xotodon: (a) Monte Hermoso, Xotodon prominens and X. ambrosettii; (b) Huayquerías de San Carlos, X. major; (c) Paraná riverside cliffs, Entre Ríos, X. foricurvatus and X. doellojuradoi; (d) San Gregorio, San José, Uruguay, "X. smaltatus"; (e) Valle de Santa María and Puerta de Corral Quemado, X. cristatus; (f) Maimará, X. maimarensis n. sp.; (2) detail of Quebrada de Humahuaca, type locality of Xotodon maimarensis n. sp.

Argentina $\left(23^{\circ}-24^{\circ} \mathrm{S}\right)$ (Fig. 1.2). The Maimará Formation unconformably overlies the older lithologies exposed in the basin, including the Proterozoic Puncoviscana Formation, and is overlain by at least $250 \mathrm{~m}$ thick sediments corresponding to the Tilcara Formation (Pingel et al., 2013).

The most complete section of this unit is exposed in the Quebrada de Maimará, west of Maimará town $\left(23^{\circ} 37^{\prime}\right.$ S, $65^{\circ} 24^{\prime} \mathrm{W}$ ), Jujuy Province, $\sim 35 \mathrm{~km}$ south of Humahuaca town, 2800 m.a.s.l. (Fig. 1.2), where the succession thrusts eastward over Pliocene conglomerates (Salfity et al., 1984; Pingel et al., 2013). The ca. $250 \mathrm{~m}$ thick (ranging from $35 \mathrm{~m}$ to $330 \mathrm{~m}$ ) Maimará Formation at Quebrada de Maimará is composed of interbedded arkosic sandstone and conglomerates intercalated with at least seven volcanic ash layers. The deposits show an upwardly coarsening sequence developed in an ephemeral fluvial system under arid and semi-arid conditions (Galli et al., 2012). The original locality data provided with specimen JUY-P 49 indicates that it was surface collected by Dr. R. Loss on 5 January 1950, $\sim 50 \mathrm{~m}$ to the West of the Nacional Route 9 close to the southern valley of Quebrada Maimará, stratigraphically located a few meters above the horizon represented by reddishbrown finer-grained clays and siltstones where other fossils were found (Berman, 1989; Pujos et al., 2012; Abello et al., 2015). This horizon is located between two basal massive tuffs correlated with 10HUM02 and 10HUM21 of Pingel et al. (2013, fig. $2 \mathrm{~B}$ ), dated at $\sim 5.06$ and $\sim 5.9 \mathrm{Ma}$, respectively. Although the occurrence of the better-preserved fossils is restricted to fine-grained sand between the two basal tuffs of the sequence, additional fossils were also recovered from the overlying conglomeratic horizon. Considering the stratigraphic provenance of JUY-P 49 and the correlation between the associated tuffs of the section at Quebrada de Maimará with those dated by Pingel et al. (2013, fig. 3A-C; see Figs. 2.1-2.2), we infer that the age of JUY-P 49 would be near the late Miocene-early Pliocene boundary.

\section{Materials and methods}

Phylogenetic Analysis.-A parsimony analysis of the matrix (see Supplementary Data) was carried out using TNT 1.1 (Goloboff et al., 2008). We performed the analysis to evaluate the phylogenetic relationships of the studied specimens within Toxodontinae, mainly based on the phylogeny presented by Forasiepi et al. (2015). We selected the same taxa used by these authors as outgroups, namely two Notohippidae (Rhynchippus spp. Ameghino, 1897 and Pampahippus arenalesi Bond and Lopez, 1993) and two Leontiniidae (Leontinia gaudryi Ameghino, 1895 and Scarritia canquelensis Chafee, 1952). However, in this analysis, the ingroup includes all currently recognized species of Xotodon: X. foricurvatus (Ameghino, 1885); X. doellojuradoi Frenguelli, 1920; X. prominens Ameghino, 1888; X. cristatus Moreno and Mercerat, 1891; X. ambrosettii Rovereto, 1914; and X. major Rovereto, 1914. It is worth mentioning that $X$. smaltatus Kraglievich, 1932, was based only on a transported lower incisor found on the beach of San Gregorio (San José, Uruguay). Kraglievich (1932) recognized other three toxodonts at the same locality, also very poorly represented. Years later, Mones (1975) described a juvenile mandibular fragment as Xotodon cf. X. smaltatus, but later the same author regarded this species as a nomen nudum (Mones, 1986). Due to the scarce and few significant remains, we prefer to exclude $X$. smaltatus from this analysis until new material could ascertain its taxonomic validity. In turn, the holotype of Xotodon foricurvatus has been lost, but a cast of this specimen (MLP M-192) is deposited at MLP, along with two lower molar casts (MLP M-200 and MLP M-202) assigned to this taxon. 
1

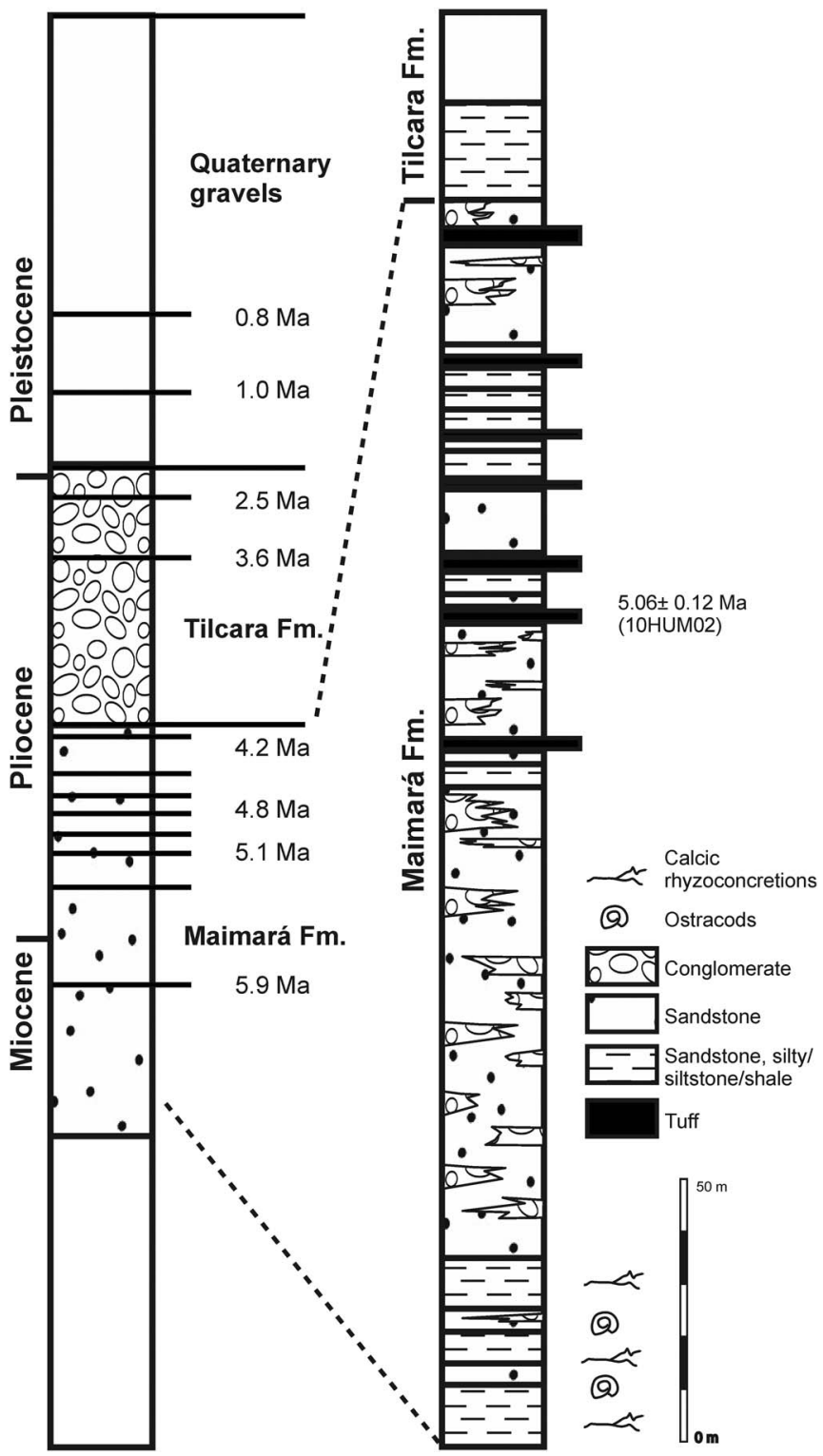

Figure 2. (1) Simplified Cenozoic chronostratigraphy of the Humahuaca Basin area (modified from Abello et al., 2015), showing Maimará and Tilcara formations and ${ }^{206} \mathrm{~Pb} /{ }^{238} \mathrm{U}$ zircon ages obtained from several volcanic ashes in Humahuaca Basin volcanic rocks (Pingel et al., 2013). (2) Stratigraphic section at Quebrada de Maimará (modified from Abello et al., 2015) showing the most basal tuffs of the section, modified from Pujos et al. (2012).

We added a third state to character 26 because some taxa exhibit a smooth posterolingual groove in P3-P4 $\left(26^{2}\right)$.

The data matrix (see Supplementary Data) comprises 31 terminal taxa and 59 morphological (cranial and dental) characters, treated as non-additive. We conducted a heuristic search with Tree Bisection Reconnection (TBR) using 100 random addition sequences and saving 20 trees per round. Subsequently, we performed a new TBR search, saving the new trees. With this methodology, we obtained 27 most parsimonious trees of 192 steps with a consistency index (CI) of 0.43 and a retention index (RI) of 0.67 . Then, we carried out searches under implied weights $(k 3-k 100)$ and from $k 6$ the program provided two most parsimonious topologies, which better established the relationships of the Xotodon clade. These trees are discussed in the corresponding section and compared with previous results (Forasiepi et al., 2015).

In the case of the analysis of radiation of the genus Xotodon, the incompleteness of the fossil record means that minimum divergence times must be established through the calculation of ghost lineages (Norell, 1996), which extend the temporal range of a lineage (a species) prior to its appearance in the fossil record based on information from its sister lineage. Calibrated phylogenetic trees were obtained using a script that takes into account the chronostratigraphic information for fossil taxa in TNT (it calculates MSM*, GER, and provides a calibrated topology in nexus format). We identified "ghost lineages" following the methodology proposed by previous authors (Pol and Norell, 2001), considering the age of the first appearance of each terminal taxon in the fossil record as the only relevant temporal information (Pol et al., 2004).

Repositories and institutional abbreviations.-The specimen JUY-P 49 is represented by an incomplete right mandibular ramus with poorly preserved dentition, part of the symphysis with the incisors (i3 broken) and canines, and a small fragment of the left ramus without teeth. This specimen is housed in the Museo de Geología Mineralogía y Paleontología (MGMyP), Instituto de Geología y Minería, Universidad Nacional de Jujuy, Argentina. JUY-P 49 was found by Dr. R. Loss on January 5, 1950, in the outcrops of Maimará Formation, in the Quebrada de Maimará west of Maimará town (Fig. 1.2). Morphometric and taxonomic studies included direct comparisons with material assigned to several species of Neogene toxodontids deposited in various national institutions, and bibliographical research focused on South American Toxodontidae (e.g., Madden, 1990, 1997; Saint-André, 1993; Nasif et al., 2000; Bond et al., 2006, and Forasiepi et al., 2015). FMNH-P, Field Museum of Natural History, Vertebrate Paleontological Collections, Chicago, USA; JUY-P, Museo de Geología, Mineralogía y Paleontología, Instituto de Geología y Minería, Universidad Nacional de Jujuy, San Salvador de Jujuy, Argentina; MACN, Museo Argentino de Ciencias Naturales "Bernardino Rivadavia", Buenos Aires, Argentina; MLP, Museo de La Plata, La Plata, Argentina; MMP, Museo Municipal de Ciencias Naturales "Lorenzo Scaglia", Mar del Plata, Argentina; PVL, Facultad de Ciencias Naturales e Instituto Miguel Lillo, Sección de Paleovertebrados Lillo, San Miguel de Tucumán, Argentina.

\section{Systematic paleontology}

Anatomical abbreviations.—c, canine; i, incisor; m, molar; p, premolar.

Class Mammalia Linnaeus, 1758

Order Notoungulata Roth, 1903

Suborder Toxodontia Owen, 1853

Family Toxodontidae Gervais, 1847

Subfamily Toxodontinae Trouessart, 1898

Genus Xotodon Ameghino, 1887

Type species.-Xotodon foricurvatus (Ameghino, 1885), "Mesopotamiense" (lower member of the Ituzaingó Formation, 
late Miocene), Entre Ríos Province, northeast Argentina (Brunetto et al., 2013).

Other species.-Besides the type species, $X$. doellojuradoi, $X$. prominens, X. cristatus, X. major, and X. ambrosettii (see Fig. 1.1). See comments above on the taxonomic validity of X. smaltatus.

Generic diagnosis.—(after Pascual et al., 1966): Toxodontid with skull high and compressed, narrow palate and quite excavated. Highly compressed premolars, arranged in closed series; P1 crescent-shaped, with labial convexity, with a layer of labial and lingual enamel; P2 with a convex labial face. Upper molars with the anteroposterior diameter very oblique with respect to the direction of the jugal series; postero-lingual lobe shorter than Hemixotodon; M3 without lingual groove, and enamel almost reaching the postero-labial side. Lower molars with lingual enamel extended anteriorly and the anterolingual column short and prominent.

Xotodon maimarensis new species

Figures 3.1-3.3, 4.1-4.3, Tables 1, 2

Holotype.-JUY-P 49: incomplete mandible with right horizontal ramus with all teeth, symphysis with all incisors, and a small fragment of the left ramus without teeth. Maimará Formation (late Miocene-early Pliocene), Jujuy Province, northwestern Argentina.

Diagnosis.-Lower incisors more procumbent than in $X$. cristatus, $X$. major, and X. prominens; symphysis long and narrow with slight divergence of its lateral borders; chin angle lower than in Xotodon major, X. cristatus, and Calchaquitherium mixtum, rather different from Mixotoxodon larensis and Toxodon sp.; chin bulging at the level of $\mathrm{p} 2-3$, which continues anteriorly in a short labial keel more marked than in X. major; the bulge limits strong lateral concavities.

Occurrence.-Maimará Formation (late Miocene-early Pliocene), outcropping at the west of National Route 9 and Maimará town $\left(23^{\circ} 37^{\prime} 27^{\prime \prime} \mathrm{S}, 65^{\circ} 24^{\prime} 48^{\prime \prime} \mathrm{W}\right)$, Quebrada de Maimará, Jujuy Province, Argentina. Note that the most fossiliferous levels at Quebrada de Maimará, where we recently collected the first vertebrates with precise stratigraphic provenance for this formation (Pujos et al., 2012; Candela et al., 2013; Abello et al., 2015), are located between the most basal tuffs of the section that outcrops west of Maimará town.

Description.-The mandible is high, with short diastemata anterior and posterior to the canine and p1. In lateral view (Figs. $3.1,4.1)$ the incisors appear procumbent. The horizontal ramus is higher at the level of $\mathrm{p} 4-\mathrm{m} 1$ than posteriorly (Table 1), and its ventral margin is straight, without a ventral projection. The alveolar margin is slightly divergent with respect to the ventral margin from $\mathrm{m} 3$ to $\mathrm{p} 2-3$. At $\mathrm{p} 3-4$ level, the horizontal ramus is narrow and projects ventrolaterally in a little expanded edge.

In occlusal view (Figs. 3.2, 4.2), the symphysis is completely fused, narrow and long, forming a well-developed
U-shaped channel, barely widening forward; the posterior end of the symphysis reaches the level of p3-4.

In ventral view (Figs. 3.3, 4.3), both hemimandibles converge at the level of the ventrolateral expansion, forming a bulging chin that continues ahead into a centered short keel (Fig. 3.3), which would correspond to the "keeled chin" sensu Madden (1990, 1997). From this level, the symphysis widens and becomes labially flattened.

Concerning preserved dentition (Figs. 3, 4; Table 2), the incisors are heteromorphic, as in the most advanced Toxodontidae (Bond et al., 2006). The i1 and i2 are small and triangular in cross section, labio-lingually compressed, with an enamel band covering the mesial and labial sides and a narrow lingual enamel band near the mesial corner. The i3 are tusk-like and deeply implanted. They are subtriangular, mesially wide and with distally directed apices, with a round vertex (Fig. 3.2). The lingual enamel band is larger than the labial one, covering approximately three quarters of the lingual side; the mesial side lacks enamel.

The canine and the premolars are broken. The canine is separated from i3 and p1 by a short diastema; it is oval in cross section and bears a narrow enamel band on its labial side. The 1 is laterally compressed and approximately similar in size to $\mathrm{p} 2$ and $\mathrm{p} 3$ (Table 2). The $\mathrm{p} 2$ is separated from $\mathrm{p} 1$ by a short diastema; the posterior portion of $\mathrm{p} 2$ is broken, and is flattened transversally. Enamel covers the labial and lingual sides, both of which are smoothly concave. The $\mathrm{p} 3$ is similar to $\mathrm{p} 2$, but it is not possible to ascertain whether it has an enamel band. The p4 is the largest of the premolar series (Table 2). It is anteroposteriorly elongated, with lingual and labial enamel, and bears a smooth fold on the labial side.

The molars are euhypsodont (sensu Mones, 1982). Their crowns, typical of advanced toxodontids (Bond et al., 2006), are long and narrow, with a wide and labially convex trigonid and a long talonid that constitutes more than half of the molar (Figs. 3.2-4.2). These teeth present some characteristics indicated by Pascual et al. (1966) for Xotodon, such as the lingual enamel extended anteriorly, the paraconid extended laterally and anteroposteriorly short, and m1-2 with a slight lingual convexity. In addition, they present four columns and two lingual sulci as in Dinotoxodon Mercerat, 1895 or Toxodon, but they differ from these genera in depth of the sulci, outline of the columns, and contact between them. The labial side is completely covered by enamel in m1-3 and exhibits a deep and wide fold, posterior to the level of the anterior lingual fold.

In the m1-2 the meta-entoconid fold is deeper, closer, and directed more obliquely forward than the ento-hypoconid fold. The lingual enamel starts at the level of the anterior fold and reaches the posterior end of the hypoconulid, which is slightly extended lingually. The postero-labial angle of these teeth is well marked.

In $\mathrm{m} 3$, the talonid is longer than in $\mathrm{m} 1-2$, and the ectoloph bears a smooth concavity opposite to the ento-hypoconid fold. The postero-labial angle is more open than in $\mathrm{m} 1-2$, as a regular convexity.

Etymology.-Named after Maimará, a small town located in Tilcara Department, Jujuy Province, Argentina; the name is an Omaguaca (native language) word meaning "falling star." 

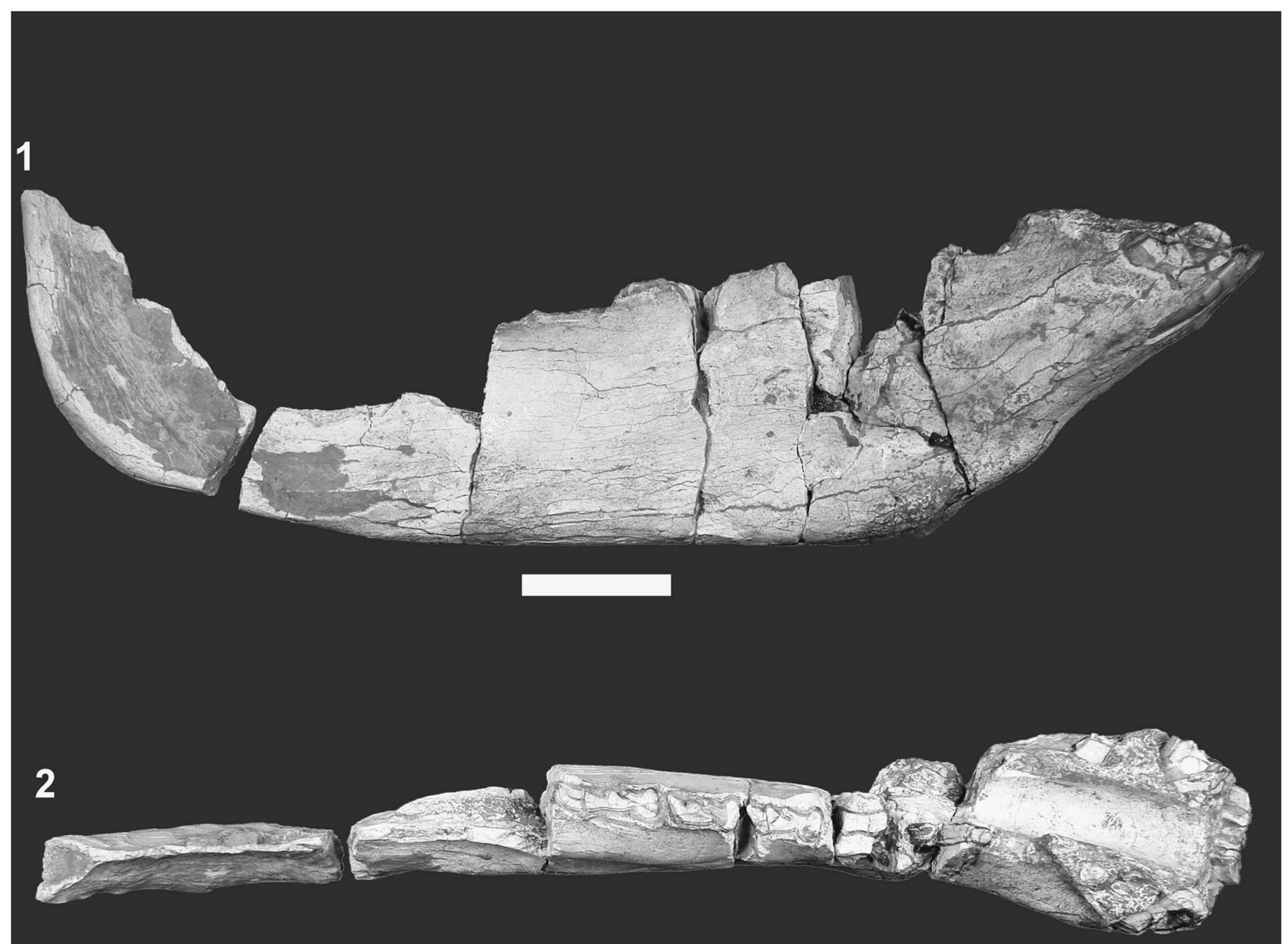

3

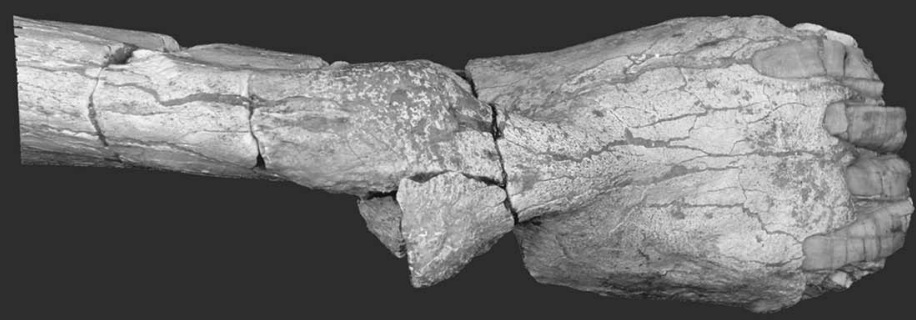

Figure 3. JUY-P 49, mandibular fragment, holotype of Xotodon maimarensis n. sp.: (1) lateral view; (2) occlusal view; (3) ventral view. Scale bar $=5 \mathrm{~cm}$.

Remarks.-Considering the generic characteristics mentioned above, JUY-P 49 is compared primarily with the species of Xotodon, as well as with other advanced toxodontines.
The angle between the symphysis and the ventral margin of the horizontal ramus in JUY-P 49 is $\sim 35^{\circ}$, similar to Posnanskytherium Liendo Lazarte, 1943, and a bit lower than in 
Xotodon major (MACN PV 8570, 45º). Xotodon cristatus has a more upraised symphysis, $\sim 60^{\circ}$, similar to Calchaquitherium mixtum Nasif, Musalem, and Cerdeño, $2000\left(\sim 58^{\circ}\right)$, which also is greater than in JUY-P 49. Toxodon Owen, 1837 and Mixotoxodon larensis Van Frank, 1957 present a very small angle $\left(\sim 20^{\circ}\right)$ and protruding symphysis, and clearly differ from JUY-P 49 by the convex ventral profile of the horizontal ramus.

Regarding the mandibular features, JUY-P 49 shows a labial keel located at a basal position of the symphysis similar to, but less marked than, that observed in the other species of Xotodon. It differs from Calchaquitherium mixtum, in which the keel is thinner and more proximally placed. In addition, the symphysis of JUY-P 49 has a flattened surface anterior to the keel, as in C. mixtum, Posnanskytherium desaguaderoi Liendo Lazarte, 1943, X. major, X. cristatus, and X. prominens.

The presence of a completely fused, U-shaped symphysis constitutes a similar feature to that observed in $X$. cristatus, $X$. major, and $C$. mixtum, but in these species the symphysis is shallower and more elevated. In addition, the posterior border of the symphysis reaches the level of p3-4 similar to $X$. cristatus, $X$. prominens, and $X$. ambrosettii.

The greatest height of the horizontal ramus of JUY-P 49 occurs at the same level as in C. mixtum. The lack of a ventral projection differentiates JUY-P 49 from Dinotoxodon paranensis (Laurillard in d'Orbigny, 1842), Pericotoxodon platignathus Madden, 1997, Gyrinodon quassus Hopwood, 1928, and Hoffstetterius imperator Saint-André, 1993.

The morphology of i1 is similar to that observed in $X$. prominens, whereas it differs from $X$. major by the absence of a lingual concavity and lesser labiolingual compression. The i2 differs from those of $X$. major, X. prominens, and X. cristatus because in these species it is crescent-shaped and presents a lingual concavity. The enamel bands of i1 and i2 show a similar arrangement to that in the species of Xotodon, as well as in

Table 1. Mandibular measurements $(\mathrm{mm})$ of Xotodon maimarensis $\mathrm{n}$. $\mathrm{sp}$. (JUY-P 49, holotype).

\begin{tabular}{lc}
\hline Maximum length of the horizontal ramus (from p2 level backward) & 310 \\
Maximum length of the vertical ramus & 55 \\
Symphyseal labial length & 70 \\
Maximum height of the horizontal ramus (p4-m1 level) & 75 \\
Maximum height of the vertical ramus & 85 \\
Width of the horizontal ramus at p2 level & 26.4 \\
Width of the horizontal ramus at m3 level & 28.1 \\
\hline
\end{tabular}

Mixotoxodon larensis, Calchaquitherium mixtum, and Pericotoxodon platignathus. The i3 of JUY-P 49 is more rounded mesially and less compressed bucco-lingually than in $X$. major and $X$. prominens. Moreover, the lingual enamel band is broader than the labial one, as it occurs in $X$. cristatus, $X$. major, Pericotoxodon platignathus, Palyeidodon obtusum Roth, 1899, Hoffstetterius imperator, and Calchaquitherium mixtum.

The presence of a diastema between $\mathrm{i} 3$ and p1 occurs in the species of Xotodon as well as in Pericotoxodon platignathus, Toxodon platensis Owen, 1837, Hoffstetterius imperator, Trigodon gaudryi, and Hyperoxotodon speciosus (Ameghino, 1887). Although the species of Posnanskytherium present a lingually extended short paraconid that lacks enamel, they differ from JUY-P 49 in lacking an ento-hypoconid fold.

The p1 is oval in cross section (Figs. 4, 5) as in Xotodon cristatus, $X$. major, and C. mixtum, differing from $X$. prominens, in which this tooth is transversely compressed.

The p2-3 of JUY-P 49 are transversely compressed as in other species of Xotodon, and differ from Calchaquitherium mixtum, in which the $\mathrm{p} 1$ is oval in cross section and similar in size to p2-3.

The p4 is proportionally similar to that of species of Xotodon and to C. mixtum, while its labial sulcus is less marked than in $C$. mixtum and $X$. ambrosettii, and similar to the condition in $X$. major and $X$. cristatus.

The lower molars exhibit an anterior fold, which is placed anterior to the level of the labial groove, as in Xotodon, Toxodon, and other toxodontids.

The metaconid of the $\mathrm{m} 1$ (Figs. 4, 5) is slightly more concave than in $X$. doellojuradoi, X. ambrosettii, X. cristatus, and $X$. major. The meta-entoconid fold is more developed than the posterior ento-hypoconid, as in most of species of Xotodon, except $X$. prominens, in which both folds are barely marked. The entoconid is more developed than in $X$. prominens and $X$. major. The hypoconulid does not protrude lingually with respect to the metaconid as in $X$. doellojuradoi. The posterior labial edge is more angular than in the other species of Xotodon, and is particularly different from those of X. cristatus and $X$. prominens. The posterior margin of the tooth is labiolingually orientated, differing from the other species of the genus. The labial concavity opposite to the ento-hypoconid fold is less marked than in X. major and X. ambrosettii.

The hypoconulid of $\mathrm{m} 2$ is more compressed anteroposteriorly than in the other species of Xotodon, and is somewhat

Table 2. Lower cheek teeth dimensions $(\mathrm{mm})$ of Xotodon maimarensis $\mathrm{n}$. sp. (JUY-P 49, holotype) and other species of Xotodon. $\mathrm{L}=\mathrm{Length}$, W $=$ width, $*=$ approximately.

\begin{tabular}{|c|c|c|c|c|c|c|c|c|c|}
\hline Taxa & & $\mathrm{c}$ & p1 & $\mathrm{p} 2$ & p3 & $\mathrm{p} 4$ & $\mathrm{~m} 1$ & $\mathrm{~m} 2$ & $\mathrm{~m} 3$ \\
\hline Xotodon maimarensis $\mathrm{n}$. $\mathrm{sp}$. & $\mathrm{L}$ & 8.12 & $7.16^{*}$ & - & $8.1^{*}$ & $15.6^{*}$ & 25.7 & $24.6^{*}$ & 35.86 \\
\hline (JUY-P 49, holotype) & $\mathrm{W}$ & 5.05 & $5.2 *$ & $5.9 *$ & $6.3^{*}$ & $9.4 *$ & 10.35 & $8.4^{*}$ & 10.7 \\
\hline Xotodon major & $\mathrm{L}$ & 9.1 & 7.7 & $14.7 / 14$ & $17.4 / 18.5$ & $20.3 / 20.4$ & $32.4 / 31.7$ & $31.7 / 32.2$ & $42.5 / 43.2$ \\
\hline (MACN PV 8578, holotype) & $\mathrm{W}$ & 5.4 & 5.5 & $6.8 / 6.5$ & $8.5 / 8$ & 9/8.8 & $10 / 9.2$ & $9.9 / 10$ & $8.4 / 9.2$ \\
\hline Xotodon doellojuradoi & $\mathrm{L}$ & - & - & - & - & - & 26.65 & 26.77 & 33.61 \\
\hline (MLP 52-X-6-21, holotype) & $\mathrm{W}$ & - & - & - & - & - & 7.6 & 8.9 & 6 \\
\hline Xotodon foricurvatus & $\mathrm{L}$ & - & - & - & - & - & - & 27.28 & - \\
\hline (MLP M-200) & $\mathrm{W}$ & - & - & - & - & - & - & 9.98 & - \\
\hline Xotodon ambrosettii & $\mathrm{L}$ & - & 7.54 & 16.59 & 15.58 & 16.64 & 24.64 & 24.69 & 32.38 \\
\hline (MACN 7965, holotype) & $\mathrm{W}$ & - & 4.67 & 7.68 & 9.37 & 9.79 & 12.15 & 11.27 & 10.16 \\
\hline Xotodon prominens & $\mathrm{L}$ & 7 & 10 & 19 & 16 & - & 24.9 & 25.4 & 34.3 \\
\hline (MACN 7708) & $\mathrm{W}$ & 5 & 5 & 11 & 7.5 & - & 10.5 & 11.4 & 10.6 \\
\hline Xotodon cristatus & $\mathrm{L}$ & 8.7 & $10.8 *$ & 12.6 & 13.8 & 20 & 30.3 & $28^{*}$ & 35.9 \\
\hline (MLP 12-1672, holotype) & $\mathrm{W}$ & 4.1 & $4.3 *$ & 6.2 & 7.9 & 10.5 & 9.4 & 10.3 & 10.5 \\
\hline
\end{tabular}



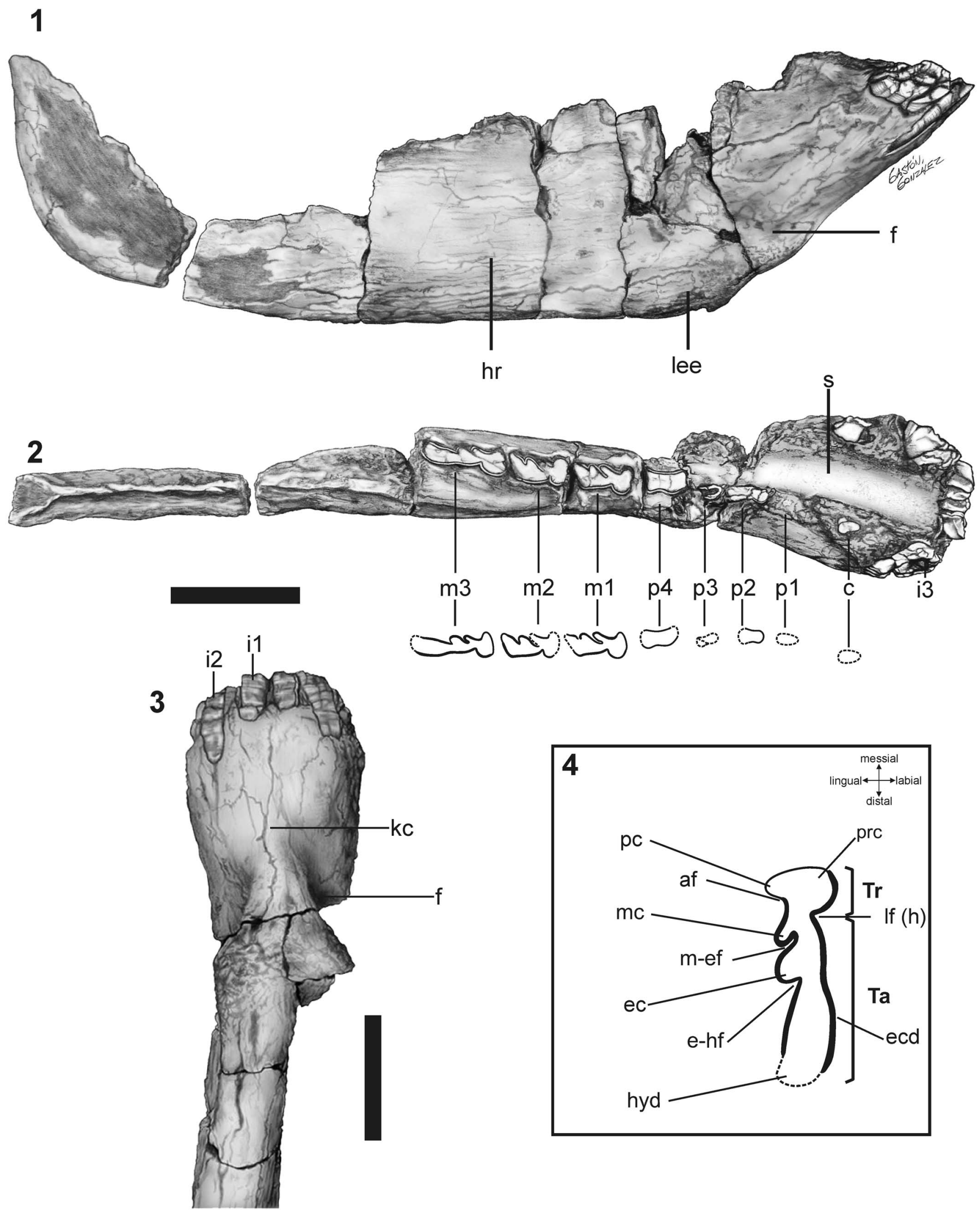

Figure 4. Drawing of the holotype of Xotodon maimarensis $\mathrm{n}$. sp. indicating mandibular and dental features used in the text: (1) lateral view; (2) occlusal view; (3) ventral view. Scale bars $=5 \mathrm{~cm}$; (4) schematic lower tooth morphology and terminology. Abbreviations: af, anterior fold; c, canine; ec, entoconid; e-hf, ento-hypoconid fold; ecd, ectolophid; f, fossa; hr, horizontal ramus; hyd, hypoconulid; i, incisor; kc, keeled chin; lee, lateral expanded edge; lf(h), labial fold (hypoflexid); m, molar; mc, metaconid; m-ef, meta-entoconid fold; p, premolar; pc, paraconid; prc, protoconid; s, symphysis; Ta, talonid; Tr, trigonid. 

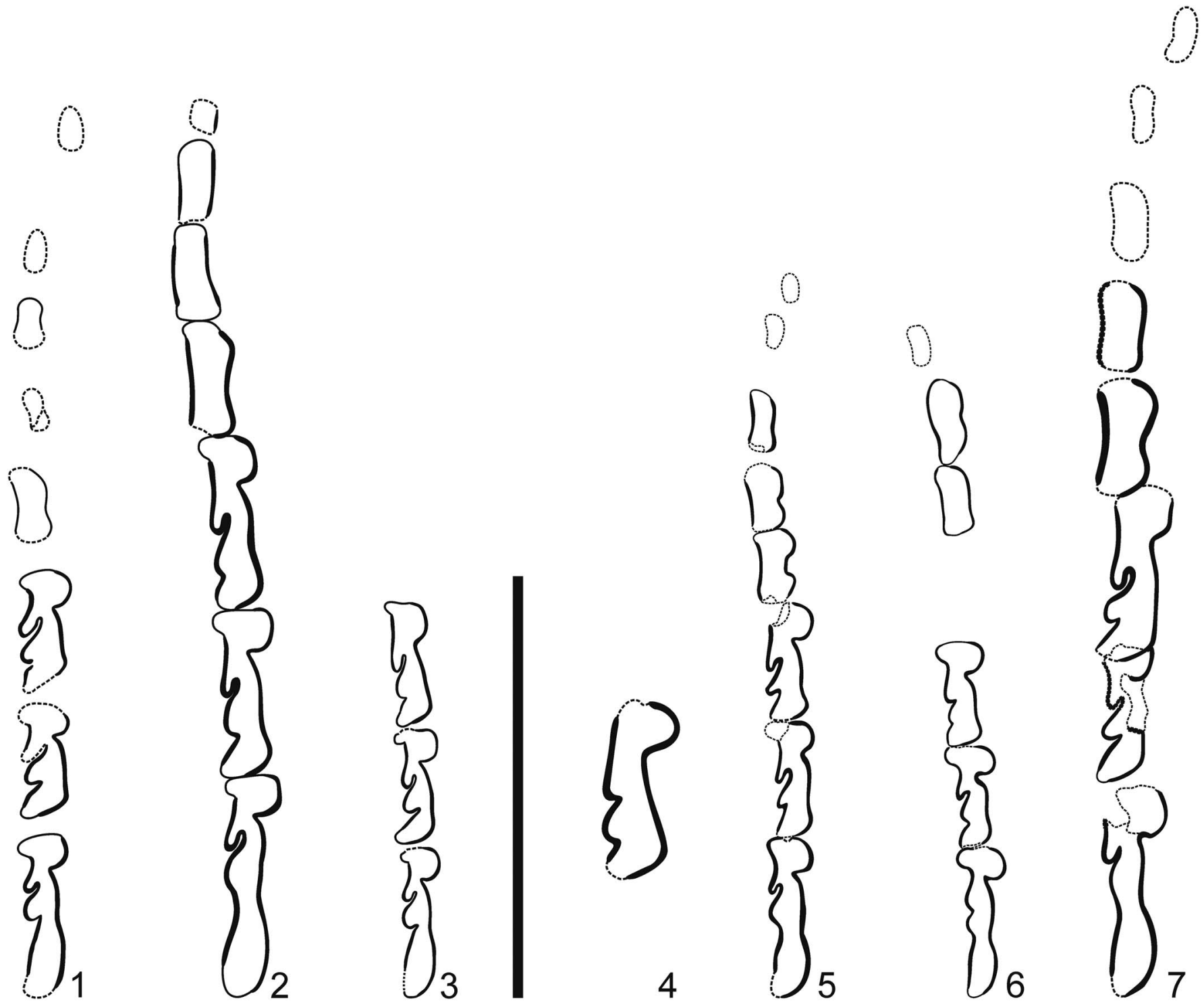

Figure 5. Schematic occlusal views of right c-m3 series: (1) Xotodon maimarensis n. sp. (JUY-P 49, holotype); (2) Xotodon major (MACN PV 8578, holotype); (3) Xotodon doellojuradoi (MLP 52-X-6-21, holotype); (4) Xotodon foricurvatus (MLP M-202); (5) Xotodon ambrosettii (MACN 7965, holotype); (6) Xotodon prominens (MACN 7708); (7) Xotodon cristatus (MLP 12-1672, holotype). Scale bar $=10 \mathrm{~cm}$.

extended lingually as in $X$. doellojuradoi and $X$. major. Moreover, the ento-hypoconid fold is deeper than in $X$. prominens, $X$. ambrosettii, and $X$. major, and similar to the specimen FMNH-P 14516 assigned to Xotodon sp.

The m3 of JUY-P 49 is very similar to that of $X$. doellojuradoi and differs from the other species of Xotodon in the greater development of the ento-hypoconid fold, although it can also be well developed in $X$. cristatus. However, as in other toxodontines (e.g., Pericotoxodon, Gyrinodon, Calchaquitherium, Mixotoxodon, and Hoffstetterius), the ento-hypoconid fold is less developed than the meta-entoconid fold.

Concerning size (Table 2), the p3-p4 of JUY-P 49 are smaller than homologous teeth of the other species of Xotodon, but their dimensions are approximate due to their incompleteness; the precedent teeth are approximately similar in size.
Molars are shorter than in $X$. major and X. cristatus, and closer to the remaining species.

According to the preceding description and discussion, the assignment of JUY-P 49 to Xotodon is based on the mandibular morphology (angled chin and straight ventral profile), the enamel of molars extended anteriorly, and paraconid of these teeth projected lingually. However, the specimen differs from known species of Xotodon in the lesser upraised and relatively longer symphysis and, especially, in the presence of a bulging chin; the bulge limits strong lateral concavities (strong ventrolabial narrowing at p2-3 level) and continues anteriorly in a short median keel. Other differences occur in cheek teeth, in which the $\mathrm{m} 1$ has the metaconid hardly more concave than in $X$. doellojuradoi, X. ambrosettii, X. cristatus, and X. major; the posterior border of the tooth is labio-lingually orientated, in contrast to the other species; the hypoconulid of $\mathrm{m} 2$ is more 
compressed anteroposteriorly; and the $\mathrm{m} 3$ has the entohypoconid fold more developed. We consider these differences enough to justify that JUY-P 49 represents a new species of Xotodon, X. maimarensis n. sp.

\section{Discussion}

Phylogenetic position of Xotodon maimarensis $n$. sp.-As mentioned above, two topologies were obtained under implied weights $(k 6-k 100)$. Given that the only difference between them occurs in the Xotodon clade, we just present here the first topology complete (Fig. 6.1) and the Xotodon clade (node 20) of the second tree (Fig. 6.2), where the position of X. maimarensis n. sp. changes.

We follow primarily the phylogeny presented by Forasiepi et al. (2015), except for this analysis, 14 characters were recodified for Xotodon spp. (0, 1, 3, 11, 16, 26, 33, 38, 39, 41, 43 $50,52,57)$ after a new revision of some specimens (X. cristatus: MLP 12-1672, holotype, and MACN PV 8093; X. major: MACN PV 8578, holotype). Although the main relationships among major clades were recovered, we identified some differences with the abovementioned work. The topology (Fig. 6.1) differs from the phylogeny of Forasiepi et al. (2015) in the outgroup relationships in that Rhynchippus appears separated from the leontiniids Scarritia and Leontinia, and an additional synapomorphy $\left(2^{1}, 9^{1}, 17^{2}\right)$ supports this branch. The monophyly of Toxodontidae (node 1) is supported by seven synapomorphies $\left(0^{1}, 20^{1}, 29^{1}, 35^{1}, 37^{1}, 39^{3}, 47^{1}\right)$ instead of two, and the relationships between Adinotherium and Nesodon are supported by five synapomorphies (node 2 : $6^{1}, 7^{1}, 15^{0}, 16^{1}, 18^{1}$ ) instead of two. Another difference appears in node 4 (node 5 in Forasiepi et al., 2015), which includes all Toxodontinae (sensu Nasif et al., 2000), because it appears as a new synapomorphy $\left(18^{2}\right.$ : check teeth hypsodont, without roots). A synapomorphy also adds to node 5: presence of a diastema behind i3 $\left(41^{1}\right)$. In contrast, only one synapomorphy supports node 6: P2 without groove or fossette $\left(24^{1}\right)$. This node splits into two major clades. The first one (node 7) is supported by the absence of upper canine ( $\left.22^{1}\right)$; along this clade, Posnanskytherium desaguaderoi represents the first divergence, occupying a more basal position than in the previous analysis. The previously recovered relationships among Andinotoxodon bolivariensis, Dinotoxodon paranensis, Toxodon platensis, Gyrinodon quassus, Ocnerotherium intermedium, and Hoffstetterius imperator are maintained. The second major clade (node 13) is supported by: sigmoid zygomatic arch $\left(6^{1}\right)$, occipital condyles projecting backward $\left(7^{1}\right)$, and P3-4 without groove or fossette $\left(26^{1}\right)$. This clade includes Nonotherium hennigi as the sister group of two minor clades (node 14: $5^{0}$ ). One of these, supported by three synapomorphies (node 15: $21^{0}, 23^{1}, 25^{1}$ ), is formed by [Pericotoxodon platignathus ((Paratrigodon euguii, Trigodon gaudryi) (Pisanodon nazari (Calchaquitherium mixtum, Mixotoxodon larensis)))].

The other one, supported by $\mathrm{m} 1-\mathrm{m} 2$ with well-developed anterior fold (node 20: $47^{\circ}$ ), groups the species of Xotodon. In node 21 of the first topology (Fig. 6.1), X. ambrosettii appears

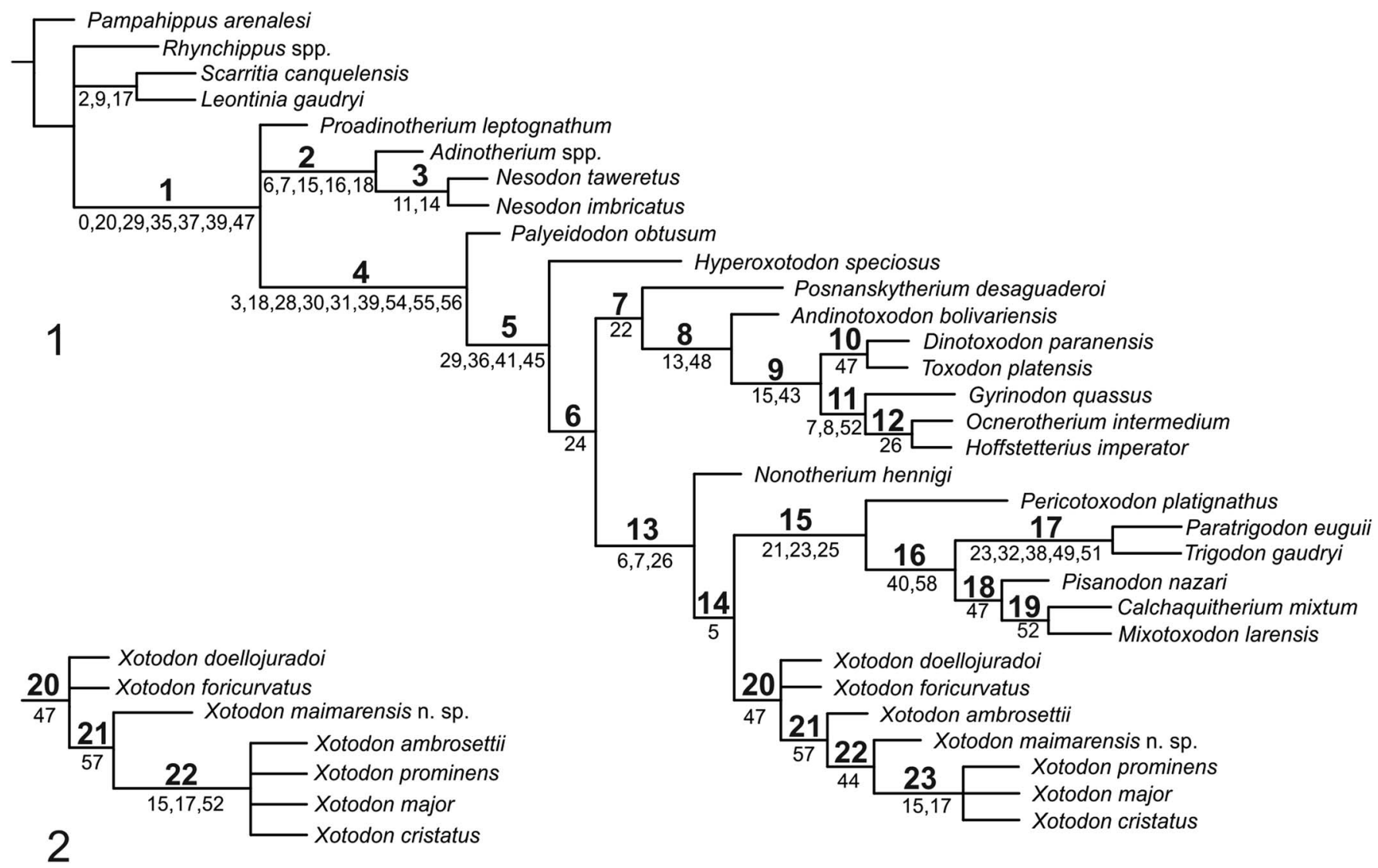

Figure 6. Phylogenetic relationships of Toxodontidae derived from the analyses performed under implied weights $(k=6)$ : $(\mathbf{1})$, first topology obtained; (2), detail of the variation in the second topology within the Xotodon clade. 


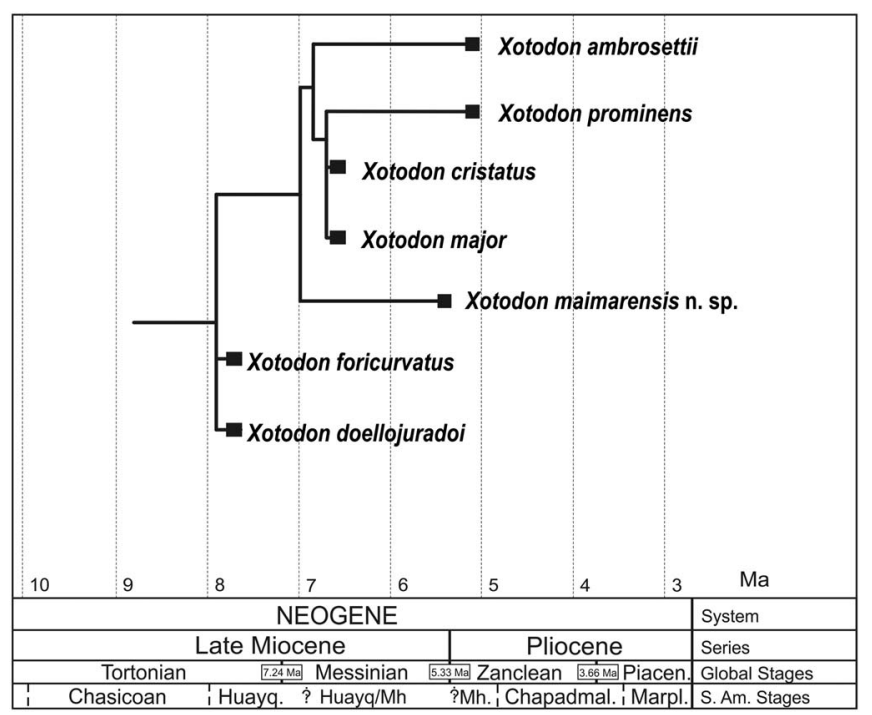

Figure 7. Chronostratigraphic calibration of the phylogenetic analysis. Abbreviations: Huayq., Huayquerian; Ma, mega annum; Marpl., Marplatan; Mh., Montehermosan; Piacen., Piacenzian; S. Am., South American.

as the sister group of $X$. maimarensis $\mathrm{n}$. sp., which represents the sister group of the clade (X. prominens, X. major, X. cristatus). This relationship varies, however, in the second topology (Fig. 6.2) because X. maimarensis n. sp. results in the sister group of the clade formed by $X$. ambrosettii, $X$. prominens, $X$. major, and $X$. cristatus in node 21 , although the relationships among these four species are not resolved. In both cases, the phylogenetic position of $X$. maimarensis n. sp. supports the taxonomic interpretation of JUY-P 49 as a new species of the genus Xotodon.

Radiation of the genus Xotodon.-Xotodon was widely distributed during the Neogene in Argentina, and it was the most diversified Neogene Toxodontidae. The new species of Xotodon increases the knowledge on the radiation of Toxodontinae in northwest Argentina. The oldest known records of Xotodon come from late Miocene beds in northeast Argentina (Entre Ríos Province). The two species recorded from these beds, $X$. foricurvatus and $X$. doellojuradoi, are only known by mandibular fragments and isolated teeth. The relatively limited Huayquerian fossil record does not indicate by itself the occurrence of a radiation during this time. However, when the obtained phylogenetic hypotheses are calibrated against the geological age of fossil taxa, a basal radiation of Xotodon is revealed by the presence of three ghost lineages that must have originated during the late Miocene (in addition to the two species recorded for this age; Fig. 7). These ghost lineages provide a minimum estimate for the age of the major diversification of Xotodon that predated the Miocene/Pliocene boundary (5.3 Ma).

\section{Conclusions}

The complete study of the toxodontid specimen JUY P-49 from the Maimará Formation (late Miocene-early Pliocene), Jujuy Province, northwestern Argentina, indicates that it should be identified as a new species of the genus Xotodon. Xotodon maimarensis n. sp. exhibits some general characters of the genus, such as the lingual enamel extended anteriorly, the paraconid extended laterally and anteroposteriorly short, and m1-2 with a slight lingual convexity. However, JUY P-49 also has some characteristics that distinguish it as a new species: symphysis long and narrow with the slight divergence of its lateral borders; strong procumbence of lower incisors and deeply implanted i3; chin angle lower than in $X$. major and $X$. cristatus, and bulging labial keel limiting strong lateral concavities. The phylogenetic analysis provided two topologies that support the taxonomic interpretation of the specimen JUY P-49 as pertaining to the genus Xotodon. Our results indicate that the major diversification of Xotodon predated the Miocene/Pliocene boundary (5.3 Ma). The new species increases knowledge of the diversity and radiation of this group of notoungulates in northwest Argentina.

\section{Acknowledgments}

We thank the anonymous reviewers and Editor of the Journal for their critical and valuable comments that improved the quality and clarity of this paper. Thanks to B. Coira and C. Galli for their support during fieldwork at Quebrada de Humahuaca. We particularly thank A. Rivero for her valuable assistance during our work at the Museo de Geología, Mineralogía y Paleontología (Instituto de Geología y Minería, Universidad Nacional de Jujuy) and S.H. del Pino for his help during the calibration of Xotodon clades. We also thank D. Voglino and G. González for illustrations.

\section{Accessibility of supplemental data}

Data available from the Dryad Digital Repository: http://doi. org/10.5061/dryad.3111m

\section{References}

Abello, M.A., De Los Reyes, M., Candela, A.M., Pujos, F., Voglino, D., and Quispe, B.M., 2015, Description of a new species of Sparassocynus (Marsupialia: Didelphoidea: Sparassocynidae) from the late Miocene of Jujuy (Argentina) and taxonomic review of Sparassocynus heterotopicus from the Pliocene of Bolivia: Zootaxa, v. 3937, p. 147-160.

Ameghino, F., 1885, Nuevos restos de mamíferos fósiles oligocenos recogidos por el Profesor Pedro Scalabrini y pertenecientes al Museo Provincial de la ciudad de Paraná: Boletín de la Academia Nacional de Ciencias de Córdoba, v. 8, p. 1-207.

Ameghino, F., 1887, Observaciones generales sobre el orden de mamíferos extinguidos sudamericanos llamados Toxodontes (Toxodontia) y sinopsis de los géneros y especies hasta ahora conocidos: Obras completas y correspondencia científica, v. 5, p. 355-431.

Ameghino, F., 1888, Rápidas diagnosis de algunos mamíferos fósiles nuevos de la República Argentina: Obras completas y correspondencia científica, v. 5, p. 469-481.

Ameghino, F., 1895, Première contribution à la connaissance de la faune mammalogique des couches à Pyrotherium: Boletín del Instituto Geográfico Argentino, v. 15, p. 603-660.

Ameghino, F., 1897, Mammifères crétacés de l'Argentine (Deuxième contribution à la connaissance de la faune mammalogique des couches à Pyrotherium): Boletín del Instituto Geográfico Argentino, v. 18, p. 406-521.

Berman, W.D., 1989, Notas sobre la sistemática y paleobiogeografía del grupo Cyonasua (Carnívora, Procyonidae) de la Argentina: $6^{\circ}$ Jornadas Argentinas de Paleontología de Vertebrados (La Plata), Actas, v. 1, p. 17-18.

Bond, M., and López, G., 1993, El primer Notohippidae (Mammalia, Notoungulata) de la Formación Lumbrera (Grupo Salta) del Noroeste argentino. Consideraciones sobre la sistemática de la Familia Notohippidae: Ameghiniana, v. 30, p. 59-68.

Bond, M., Madden, R.H., and Carlini, A.A., 2006, A new specimen of Toxodontidae (Notoungulata) from the Urumaco Formation (Upper Miocene) of Venezuela: Journal of Systematic Palaeontology, v. 4, p. 285-291. 
Bonini, R.A., 2014, Bioestratigrafía y diversidad de los mamíferos del Neógeno de San Fernando y Puerta de Corral Quemado (Catamarca, Argentina) [Ph. D. dissertation]: La Plata, Universidad Nacional de La Plata, Facultad de Ciencias Naturales y Museo de La Plata, 366 p.

Bonini, R.A., Reguero, M.A., and Candela, A.M., 2011, Un nuevo toxodóntido (Notoungulata, Toxodontidae) del Neógeno de la provincia de Catamarca (Argentina): Ameghiniana, v. 48, p 143-144R.

Brunetto, E., Noriega, J.I., and Brandoni., D., 2013, Sedimentología, estratigrafía y edad de la Formación Ituzaingó en la provincia de Entre Ríos, Argentina, in Noriega, J.I., and Brandoni, D., eds., El Neógeno de la Mesopotamia Argentina: Asociación Paleontológica Argentina, Publicación Especial, v. 14, p. 13-27.

Candela, A.M., Bonini, R., Tonni, E.P., Reguero, M., Abello, M.A., and Rasia, L.L., 2013, Palaeocavia (Rodentia, Caviidae) en la Formación Maimará (Mioceno tardío-Plioceno temprano), Quebrada de Humahuaca (Noroeste argentino): importancia bioestratigráfica y biogeográfica. II Simposio del Mioceno-Pleistoceno del Centro y Norte de Argentina, Diamante: Ameghiniana, v. 50, p 8R.

Chafee, R., 1952, The Deseadan Vertebrate Fauna of the Scarritt Pocket, Patagonia: Bulletin of the American Museum of Natural History, v. 98, p. 509-559.

Contreras, V.H., and Baraldo, J.A., 2011, Calibration of the Chasicoan Huayquerian stages boundary (Neogene), San Juan, western Argentina, in Salfiti, J., and Marquillas, R., eds., Cenozoic Geology of Central Andes of Argentina: Salta, Instituto del Cenozoico, (2011), p. 111-121.

Croft, D.A., Flynn, J.J., and Wyss, A.R., 2004, Notoungulata and Litopterna of the early Miocene Chucal Fauna, northern Chile: Fieldiana: Geology (New Series) v. 50, p. 1-49.

d'Orbigny, A.D., 1842, Voyage dans l'Amerique méridionale (le Brésil, la république Orientale de l'Uruguay, la république Argentine, la Patagonie, la république du Chili, la république de Bolivia, la république du Pérou), exécuté pendant les années 1826, 1827, 1828, 1829, 1830,1831, 1832 et 1833. Tome trosième, $4^{\circ}$ partie: Paléontologie: Paris and Strasbourg, P. Bertand and V. Levrault, $152 \mathrm{p}$.

Forasiepi, A.M., Martinelli, A.G., De La Fuente, M., Dieguez, S., and Bond, M., 2011, Notes on the paleontology and stratigraphy of the Aisol Formation (Neogene, San Rafael, Mendoza Province): New evidences. In Cenozoic Geology of the Central Andes of Argentina, in Salfiti, J., and Marquillas, R., eds., Cenozoic Geology of Central Andes of Argentina: Salta, Instituto del Cenozoico, (2011), p. 135-154.

Forasiepi, A.M., Cerdeño, E., Bond, M., Schmidt, G.I., Naipauer, M., Straehl, F.R., Martinelli, A.G., Garrido, A.C., Schmitz, M.D., and Crowley, J., 2015, New toxodontid (Notoungulata) from the Early Miocene of Mendoza, Argentina: Paläontologische Zeitschrift, v. 89, p. 635-643.

Frenguelli, J., 1920, Apuntes sobre mamíferos fósiles entrerrianos: Boletín de la Academia Nacional de Ciencias de Córdoba, v. 24, p. 27-54

Galli, C.I., Coira, L.B., Candela, A.M, Alonso, R.N., Reguero, M., Abello, M.A., de los Reyes, M., and Voglino, D., 2012, Los depósitos del Mioceno superior -Pleistoceno de la Quebrada de Humahuaca, provincia de Jujuy. "I Simposio del Mioceno-Pleistoceno del Centro y Norte de Argentina", San Migue de Tucumán ,12 al 14 de septiembre de 2012: Ameghiniana, v. 49, p 10R.

Gervais, H., 1847, Observations sur les mammifères fossiles du midi de la France: Annales des Sciences Naturelles, Zoologie (3), v. 8, p. 203-224

Goloboff, P., Farris, J., and Nixon, K., 2008, TNT, a free program for phylogenetic analysis: Cladistics, v. 24, p. 774-786.

Hopwood, A.T., 1928, Gyrinodon quassus, a new genus and species of toxodont from western Buchivacoa (Venezuela): Quarterly Journal of the Geological Society, v. 84 , p. $573-583$.

Kraglievich, L., 1932, Nuevos apuntes para la geología y paleontología uruguayas: Anales del Museo de Historia Natural de Montevideo, v. 3, p. 1-65

Liendo Lazarte, M., 1943, Nota preliminar sobre un pequeño toxodonte del altiplano Posnanskytherium desaguaderoi gen. sp. nov.: La Paz, Museo Nacional de Tihuanacu, Sección Paleontología, 12 p.

Linnaeus, C., 1758, Systema Naturae per Regna tria Naturae, secundum Classes, Ordines, Genera, Species, cum Characteribus, Differentis, Synonymis, Locis, 10th ed.: Stockholm, Sweden, Laurentii, Slavi, 824 p.

Lundelius, E., Bryant, V.M., Mandel, R., Thies, K.J., and Thoms, A., 2013, The first occurrence of a toxodont (Mammalia, Notoungulata) in the United States: Journal of Vertebrate Paleontology, v. 33, p. 229-232.

Madden, R.H., 1990, Miocene Toxodontidae (Notoungulata, Mammalia) from Colombia, Ecuador and Chile [Ph.D. dissertation]: Durham, Duke University, $407 \mathrm{p}$.

Madden, R.H., 1997, A new Toxodontid Notoungulate, in Kay, R., Madden, R. H., Cifelli, R.L., and Flynn J.J., eds., Vertebrate Paleontology in the Neotropics: The Miocene fauna of La Venta, Colombia: Washington and London, Smithsonian Institution Press, p. 335-354.

Marshall, L.G., and Patterson, B., 1981, Geology and geochronology of the mammal-bearing Tertiary of the Valle de Santa María and Río Corra Quemado, Catamarca Province Argentina: Fieldiana Geology, v. 9, p. 1-80.
Mercerat, A., 1895, Molaires de Toxodon et d'autres représentants de la même famille: Anales del Museo Nacional de Buenos Aires, v. 4, p. 207-215.

Mones, A., 1975, Notas paleontológicas uruguayas, III. Vertebrados fósiles nuevos o poco conocidos (Chondrichthyes, Osteichthyes, Amphibia, Mammalia): Ameghiniana, v. 12, p. 343-349.

Mones, A., 1982, An equivocal nomenclature: what means hypsodonty? Paläontologische Zeitschrift, v. 56, p. 107-111.

Mones, A., 1986, Palaeovertebrata Sudamericana. Catálogo Sistemático de los Vertebrados Fósiles de América del Sur Parte I. Lista Preliminar y Bibliografía: Courier Forschungsinstitut Senckenberg, v. 82, p. 1-625.

Moreno, F.P., and Mercerat, A., 1891, Exploración arqueológica de la Provincia de Catamarca: Paleontología: Revista del Museo de La Plata, v. 1, p. 1-71.

Nasif, N., Musalem, S., and Cerdeño, E., 2000, A new toxodont from the late Miocene of Valle del Cajón (Catamarca, Argentina) and taxonomic remarks on the Family Toxodontidae (Notoungulata): Journal of Vertebrate Paleontology, v. 20, p. 591-600.

Norell, M.A., 1996, Ghost taxa, ancestors, and assumptions: a comment on Wagner: Paleobiology, v. 22, p. 453-455.

Owen, R., 1837, A description of the cranium of the Toxodon platensis, a gigantic extinct mammiferous species, referrible by its dentition to the rodentia, but with affinities to the pachydermata and the herbivorous Cetacea: Proceedings of the Geological society of London, v. 2, p. 541-542.

Owen, R., 1853, Description of some species of the extinct genus Nesodon, with remarks on the primary group (Toxodontia) of the hoofed quadrupeds to which that genus is referable: Philosophical Transactions of the Royal Society of London, v. 143, p. 291-309.

Pascual, R., 1965, Los Toxodontidae (Notoungulata) de la Formación Arroyo Chasicó (Plioceno Inferior) de la Provincia de Buenos Aires: Ameghiniana, v. 4, p. 101-132.

Pascual, R., Ortega Hinojosa, E., Gondar, D., and Tonni, E.P., 1966, Las edades del Cenozoico mamalífero de la provincia de Buenos Aires, in Borrello, A V., ed., Paleontografía Bonaerense IV Vertebrata, Comisión de Investigaciones Científicas de la provincia de Buenos Aires: La Plata, p. 165-193.

Pingel, H., Strecker, M.R., Alonso, R.N., and Schmitt, A.K., 2013, Neotectonic basin and landscape evolution in the Eastern Cordillera of NW Argentina, Humahuaca Basin ( 24 ${ }^{\circ}$ S): Basin Research, v. 25, p. 554-573.

Pol, D., and Norell, M.A., 2001, Comments on the Manhattan Stratigraphic Measure: Cladistics, v. 17, p. 285-289.

Pol, D., Norell, M.A., and Siddall, M.E., 2004, Measures of stratigraphic fit to phylogeny and their sensitivity to tree size, tree shape, and scale: Cladistics, v. 20 , p. $64-75$

Pujos, F., Candela, A., Galli, C.I., Coira, B.L., Reguero, M.A., de los Reyes, M., and Abello, M.A., 2012, The Scelidotheriine Proscelidodon (Xenarthra: Mylodontidae) from the Late Miocene of Maimará (Northwestern Argentina, Jujuy Province): Ameghiniana, v. 49, p. 668-684

Reguero, M., Bonini, R.A., Candela, A.M., and Solís, N., 2011, Un nuevo Toxodontidae (Mammalia, Notoungulata) del Neógeno de la Quebrada de Humahuaca, provincia de Jujuy, Argentina: Ameghiniana, v. 48, p. 197R.

Riggs, E.S., and Patterson, B., 1939, Stratigraphy of Late Miocene and Pliocene deposits of the Province of Catamarca (Argentina) with notes on the faunae: Physis, v. 14, p. 143-162.

Rincón, A.D., 2011, New remains of Mixotoxodon larensis Van Franck 1957 (Mammalia: Notoungulata) from Mene de Inciarte tar pit, north-western Venezuela: Interciencia, v. 36, p. 894-899.

Roth, S., 1899, Apuntes sobre la geología y paleontología de los territorios de Río Negro y Neuquén (diciembre de 1895 a junio de 1896): Revista del Museo de La Plata, v. 9, p. 141-197.

Roth, S., 1903, Los ungulados sudamericanos: Anales del Museo de La Plata, Sección Paleontología, v. 5, p. 1-36.

Rovereto, C., 1914, Los estratos araucanos y sus fósiles: Anales del Museo de Historia Natural de Buenos Aires, v. 25, p. 1-247.

Saint-André, P.A., 1993, Hoffstetterius imperator n. g., n. sp. du Miocène supérieur de l'Altiplano bolivien et le statut des Dinotoxodontinés (Mammalia, Notoungulata): Compte Rendus de l'Academie des Sciences, Paris, v. 316, (Serie 2), p. 539-545.

Salfity, J.A., Brandan, E.M., Monaldi, C.R., and Gallardo, E.F., 1984, Tectónica compresiva cuaternaria en la cordillera oriental argentina, latitud de Tilcara (Jujuy): 9th Congreso Geológico Argentino (San Carlos de Bariloche), Actas, v. 2, p. 321-336.

Trouessart, E.L., 1898, Catalogus mammalium tam viventium quam fossilium: Nova editio (Prima completa), Berolini, Friedlânder \& Sohn, v. 2 , p. $665-1469$

Van Frank, R., 1957, A fossil collection from northern Venezuela. I. Toxodontinae (Mammalia, Notoungulata): American Museum Novitates, v. 1850, p. $1-38$.

Accepted 29 November 2016 